\title{
The Choice of Foreign Locations of Swiss MNEs \\ An Analysis Based on Firm Data
}

\author{
Working Paper \\ Author(s): \\ Arvanitis, Spyridon; Hollenstein, Heinz; Stucki, Tobias \\ Publication date: \\ 2012-08 \\ Permanent link: \\ https://doi.org/10.3929/ethz-a-007362334
}

Rights / license:

In Copyright - Non-Commercial Use Permitted

Originally published in:

KOF Working Papers 311 


\section{KOF Working Papers}

The Choice of Foreign Locations of Swiss MNEs

An Analysis Based on Firm Data

Spyros Arvanitis, Heinz Hollenstein and Tobias Stucki

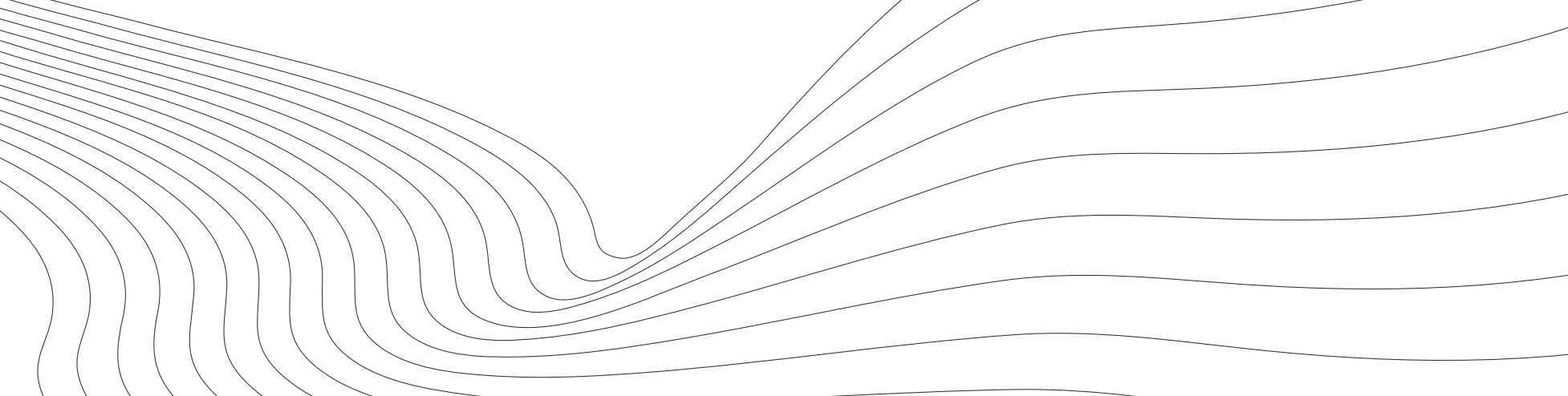




\section{KOF}

ETH Zurich

KOF Swiss Economic Institute WEH D 4

Weinbergstrasse 35

8092 Zurich

Switzerland

Phone +41446324239

Fax +41446321218

www.kof.ethz.ch

kof@kof.ethz.ch 


\section{The Choice of Foreign Locations of Swiss MNEs}

\section{An Analysis Based on Firm Data*}

Spyros Arvanitis

ETH Zurich, KOF Swiss Economic Institute

CH-8092 Zurich

Phone: +41446325168

Fax: +4144632 1234

E-Mail: $\underline{\text { arvanitis@kof.ethz.ch }}$
Heinz Hollenstein

ETH Zurich, KOF Swiss Economic Institute CH-8092 Zurich

Phone: +41 446325329

Fax: +41446321234

E-Mail: $\underline{\text { hollenstein@kof.ethz.ch }}$

\section{Tobias Stucki}

ETH Zurich, KOF Swiss Economic Institute

CH-8092 Zurich

Phone: +41446326307

Fax: +41 446321234

E-Mail: stucki@kof.ethz.ch

* The research has been supported by the Swiss State Secretariat of Economics (Seco). 


\begin{abstract}
In this paper, the parent firms' choice of FDI locations is analyzed based on a unique firm-level dataset for Swiss MNEs. The data allows a detailed characterization of parent companies, their foreign subsidiaries and the two-way trade flows between parent companies and foreign affiliates. In combination with information on the hosts regions of the FDI, the data allows to identify the factors determining the choice among nine alternative destinations. As firm-level studies are quite rare so far and, if available, are based on only few firm characteristics, this research provides substantial new insights.
\end{abstract}

Keywords: Foreign Direct Investment; Global Location Portfolios; Intra-Firm Trade JEL classification: F2 


\section{Introduction}

Over the last years foreign direct investments (FDI) have become considerably more important. Correspondingly, the theoretical and empirical literature dealing with a multitude of aspects of FDI strongly increased (for a detailed overview see, e.g., Dunning \& Lundan 2008). However, there are some topics for which empirical evidence remains relatively scarce, in particular as far as it is based on the analysis of firm data by use of econometric methods. One of these gaps refers to the firm-level investigation of the factors determining the choice of multinational enterprises (MNEs) among potential locations for their foreign activities, a decision which strongly affects the operation and profitability of a company (see e.g. Aulakh \& Teegen 2000; Beamish \& Delios 2001). Already in the late nineties, Dunning (1998) emphasized the need of a re-assessment of the role of location for MNEs that has been rather neglected until then. Cantwell (2008) provided a survey of the literature on location and the multinational enterprise, in which he stressed the issue of "firm-location interactions". One main point of his analysis was that "the diversity or heterogeneity of firms matters, as does the diversity of locational environments" (p. 35). This conclusion is a major motivation for the present study, in which we analyze econometrically the factors driving an MNE to choose a specific host region for its equity-based FDI (the term FDI is used in this paper for all forms of equity-based foreign activities of domestic companies, i.e. fully-owned affiliates, majority/minority stakes in foreign firms; equity-based joint ventures/alliances with foreign partners).

So far, the choice among alternative FDI locations has primarily been investigated with country data (see e.g. Blonigen \& Wang 2005; Brainard 1993; Eaton \& Tamura 1994; Ekholm 1998; specifically for services: Py \& Hatem, 2009) or with sub-national data (see e.g. Guimaraes et al. 2000; Barrios et al. 2006; Basile et al. 2008). These studies analyze how country/regional characteristics affect FDI flows. Blonigen \& Wang (2005), for example, found substantial differences in the factors determining FDI in less developed host countries as compared to those in advanced economies. However, macro-level studies do not take into account the heterogeneity of firms within a country/region. Therefore a more disaggregated analysis of the choice of FDI locations is required, which, in the optimal case, combines information on the parent company, its foreign affiliates and the relationship between them. The few firm-level studies available so far can be divided into two groups. The first one analyzes differences among many host countries with respect to one or very few firm characteristics. Davidson (1980), for example, investigate the impact of FDI experience of 
U.S.-based MNEs on location decisions. Shatz \& Venables (2000) analyze whether the share of U.S. and Japanese affiliate production that is sold back to the home country differs between host countries. Chen \& Moore (2010) dealt with the impact of total factor productivity of French parent firms on the choice of FDI locations. Demirbag \& Glaister (2010) investigated whether FDI experience, project type (research vs. development) and industry affiliation are able to explain the choice among five target regions characterized by different location characteristics (R\&D wages, availability of researchers, etc). In the frame of a gravity model, Nachum et al. (2008) analyzed the choice of U.S. MNEs among host locations using their proximity to the global distribution of knowledge, markets and labor endowment, a number of other country characteristics as well as firm size and sales per employee as explanatory variable.

The second group of firm-level studies draws on more detailed information on the considered firms, but at the expense of the number of host regions included in the analysis. Makino et al. (2004) investigate whether some specific characteristics of Japanese parent companies (R\&D intensity, prior host country experience, size) and their foreign subsidiaries (size, age, equity ownership) differ between FDI in less developed countries and those in developed countries. Besides, Aw \& Lee (2008) compare some characteristics of Taiwanese MNEs investing in China with those doing so in the USA. More specifically, they focus on differences with respect to productivity and innovation activity of the parent firms.

In this paper, the choice of FDI locations is analyzed based on Swiss firm-level information, which is more detailed than it is the case in previous studies using micro data. Therefore, our study shows several new features. Compared with the first group of studies mentioned above, we have at our disposal (a) richer information characterizing parent companies (first-time FDI activity, firm age, R\&D intensity, share of employees with a degree at the tertiary-level, firm size, industry affiliation); (b) more information on foreign subsidiaries (type of business function located abroad, objectives of the functional business units established abroad based on information on the motives of foreign activities); and (c) data referring to transactions between parent companies and their foreign affiliates (intra-firm trade: two-way flows of goods and services). The available firm-level information allows a detailed analysis of the decision of Swiss MNEs on the choice of location of activities abroad by use of three categories of variables: (a) FDI experience, (b) the potential for innovation and (c) the type of FDI in terms of business functions, motivation and firm-internal flows of goods/services. 
Compared with the second group of previous firm-level studies, we can use more detailed information on the destination of FDI as we are able to distinguish up to nine host regions (EU15/EFTA, Eastern Europe, Southeast Europe, Russia, North America, Latin America, China, Asian Tigers and Southeast Asia/India). In terms of regional coverage it is thus possible to present quite a complete picture. In 2009, the above-mentioned nine regions hosted more than $95 \%$ of the total capital stock of Swiss outward FDI (SNB 2011). All in all, the data set allows us to capture the heterogeneity of firms and host regions to a much higher degree than it was the case in previous studies.

The remainder of the paper is organized as follows: Section 2 provides a detailed characterization of the different FDI host regions that is used to formulate clear hypotheses on the location choice of the firms afterwards. In Section 3 we present the conceptual background of the empirical analysis and derive the main hypotheses. Section 4 describes the database. In Section 5 we discuss the methodology of our empirical analysis whose results are presented in Section 6. Finally, we summarize and draw some conclusions.

\section{Characteristics of FDI host regions}

To be able to formulate clear hypotheses about which type of firm invests in which region, we first have to characterize the different FDI host regions relative to each other and relative to Switzerland, the home country of the firms. We distinguish nine different host regions of FDI, i.e. EU15/EFTA, Eastern Europe, Southeast Europe, Russia, North America, Latin America, China, Asian Tigers and Southeast Asia/India. ${ }^{1}$ To facilitate the characterization of these regions, some of them are merged into a "main region", provided that they are not too distant from each other and show similar characteristics (selected according to their relevance in the present context). The main regions "Eastern Europe" is made up of Eastern Europe (in the narrow sense), Southeast Europe and Russia, and "Asia" comprises China, Asian Tigers and Southeast Asia/India. All in all, the analysis pertains to five main regions, i.e. EU15/EFTA, North America, Latin America, Eastern Europe and Asia, which contain a total of nine subregions.

\footnotetext{
${ }^{1}$ EU15/EFTA: Austria, Belgium, Britain, Denmark, Finland, France, Germany, Greece, Iceland, Ireland, Italy, Liechtenstein, Luxembourg, the Netherlands, Norway, Portugal, Spain and Sweden; Eastern Europe: Baltic countries, Czech Republic, Hungary, Poland, Slovakia and Slovenia; Southeast Europe: Albania, Bosnia, Bulgaria, Croatia, Macedonia, Montenegro, Romania and Serbia; Russia: Belarus, Russia, and Ukraine; North America: Canada and the USA; Asian Tigers: Hong Kong, Korea, Singapore and Taiwan; Southeast Asia/India: India, Indonesia, Malaysia, Philippine and Thailand.
} 
The five main regions are characterized by using a set of macro-level indicators that are relevant for the choice of FDI locations. The values of these measures, however, are not calculated for the main regions themselves but only for each region's three most important countries selected according to their share in the Swiss outward FDI capital stock. ${ }^{2}$ This procedure yields a representative picture of the characteristics of the five main regions as it also shows the heterogeneity in terms of the underlying characteristics within the same main region. The values of the relevant indicators for the selected countries representing each main region are shown in Table 1.

The attractiveness of a region as sales market is measured by the level and the growth rate of the purchasing power capturing the present and future demand potential. It is highest in EU15/EFTA and North America and lowest in Asia (with the exception of Singapore whose purchasing power is more or less the same as that of the Western countries). Furthermore, we note that some countries of Eastern Europe and Asia could significantly reduce the gap over the last few years.

Wage costs are relevant primarily for firms with labor intensive production processes. Compared to Western countries, these costs are much lower in Asia, Latin America and Eastern Europe. But there are also substantial differences within these low-wage regions; for example, in Mexico as well as in Indonesia and China wages are much lower than in the other countries of the respective main regions.

The innovative potential of a region is another factor attracting FDI (knowledge sourcing). According to the three indicators used to represent the innovation potential it is highest in EU15/EFTA and North America.

Moreover, the choice of host regions of FDI is determined by its distance. According to the gravity model of international trade and investment (see e.g. Brainard 1997) long distance between two countries reduces the attractiveness of FDI compared to exporting, since the costs of coordination and control of foreign affiliates are higher in case of distant locations. On the other hand high transport and communication costs are an obstacle to serving these markets by exporting and are thus an incentive for FDI. The net effect of the two opposite forces, which may differ by type of FDI (see below), will be revealed by the empirical analysis. According to Table 1, distances between Switzerland and the most important

\footnotetext{
${ }^{2}$ Germany, Britain and France for EU/EFTA; Poland, Russia and the Czech Republic for Eastern Europe; Brazil, Mexico and Venezuela for Latin America; Singapore, China and Indonesia for Asia; and, finally, Canada and USA for North America.
} 
countries of the region EU15/EFTA are shorter than those to the countries of Eastern Europe. In addition, North America is closer to Switzerland than Latin American and Asian countries.

Investment costs considerably differ among the selected countries of the five regions. They are much lower in Western countries than in all other regions, once again, with the exception of Singapore which, in this respect, is quite similar to EU/EFTA and North America. In contrast, investment costs are much higher in Brazil, Indonesia, Russia and Venezuela.

\section{Conceptual background and hypotheses}

The OLI paradigm developed by Dunning $(1993,2000)$ and the dynamic capability view of the firm (Teece et al. 1997) are used as broad theoretical background. Dunning distinguishes three groups of variables which explain international engagements of a firm: „ownershipspecific“ advantages ( $\underline{\mathrm{O}})$, „location-specific“ advantages $(\underline{\mathrm{L}})$ and ,internalizing” advantages (I). In accordance with Teece et al. (1997) and the pioneering thinking of Hymer going back to the 1960s (Hymer, 1976; see also Caves, 1982), O-advantages refer to firm-specific capabilities and assets that make a company superior to local competitors irrespective of general location characteristics. Such advantages arise from the availability of (firm-specific) human, physical and knowledge capital as well as specific intangibles such as marketing and managerial skills, etc. L-advantages represent potential gains a firm can realize by optimizing its activities along the value chain across locations. In the present context, this type of advantage primarily roots in differences among locations with respect to factors favoring or impeding distribution and production activities but also knowledge creation and use. Iadvantages can be realized through M\&A activities or by forming co-operations and alliances as means to internalize market transactions. In this way, the parent company can reduce transaction costs on the imperfect international markets (monitoring costs; enforcing quality standards, mitigating appropriability problems, etc).

In accordance with the few studies dealing with the choice of FDI locations at firm level (Aw \& Lee 2008; Davidson 1980; Makino et al. 2004; Shatz \& Venables 2000), we formulate a model that controls for several characteristics of the parent company in Switzerland and the relationship with its foreign affiliates. The results from model estimation (see Section 6) will be interpreted in the light of the hypotheses presented in this section.

\section{Vertical versus horizontal FDI}

In accordance with literature, apart from knowledge sourcing, there are two main reasons why a firm may engage in FDI, namely: (a) to better serve a local market and (b) to get access to 
low-cost inputs in order to improve competitiveness on local and international markets (Shatz \& Venables 2000). Case (a) is called "horizontal FDI", as firms typically more or less duplicate the same activities in additional plants to supply different locations. In contrast, case (b) referred to as "vertical FDI", implies that the supply chain is fragmented and some parts of it are relocated abroad in order to minimize costs.

If only firms with foreign production facilities are considered, the distinction between horizontal and vertical FDI suffices to cover the entire range of strategies among which MNEs may choose. However, one observes that many MNEs deploy abroad exclusively distribution facilities. Therefore, in the general case, firms have to decide not only between vertical and horizontal production-oriented FDI, but also between "production-oriented" and “distribution-oriented" FDI (for this distinction see Hanson et al. 2001). We thus distinguish the following types of FDI: (a) distribution-oriented FDI, (b) vertical (production-oriented) FDI and (c) horizontal (production-oriented) FDI.

Vertical FDI are expected to be deployed primarily in low-cost countries (see e.g. Blonigen \& Wang 2005). As shown in Table 1, production costs - in particular wage costs - are at lowest in Eastern Europe, Latin America and Asia. In contrast, investment costs are relatively high in these regions. It is an empirical question whether the advantage of low labor costs outweighs the disadvantage of high investment costs. We expect that, on balance, production cost advantages dominate in case of the three aforementioned regions. Accordingly, we expect them to attract primarily vertical FDI.

Horizontal FDI are associated with higher fixed costs and might thus be most common in host countries with large markets. The same is true for distribution-oriented FDI. However, the incentive for a firm to engage in distribution-oriented rather than horizontal FDI is lower if trade barriers of the host country are high. Transportation costs are another relevant factor (see e.g. Hattari \& Rajan 2009 or Mody et al. 2003). As they can be reduced by horizontal FDI, the distance between host and home country is expected to be positively correlated with the cost savings resulting from horizontal FDI compared with the distance-related cost savings in case of distribution-oriented FDI (see Hanson et al. 2001 for a similar reasoning). ${ }^{3}$ EU15/EFTA and North America are the largest (potential) markets and thus particularly attractive for horizontal FDI. However, given the lower trade barriers and shorter distance in case of EU15/EFTA, the likelihood of Swiss firms to be engaged in distribution-oriented FDI

\footnotetext{
${ }^{3}$ Cultural distance between domestic and foreign locations may have a similar effect: cost savings in case of production-oriented FDI are high compared to those that can be realized by distribution-oriented FDI.
} 
is expected to be higher in EU15/EFTA than in North America. ${ }^{4}$ The above discussion on the three types of FDI implies:

H1: North America, in the first place, attracts horizontal FDI, whereas in case of EU15/EFTA distribution-oriented FDI is predominant. Vertical FDI are hosted primarily by Eastern Europe, Latin America and Asia.

\section{FDI experience}

The stages view of foreign activities of firms conceptualizes internationalization as a sequential process, with firms exporting their products to foreign markets as the first step. It is only later on that they seek local presence through capital-based activities. At an early stage, MNEs tend to select a host country that is similar to their home country. This preference may gradually change as firms gain experience in international activities. This experience enables firms to expand their activity radius and to invest in more than one country as well as in countries that are not similar to the home country (see e.g. Johanson \& Vahlne 1977; Johanson \& Wiedersheim-Paul 1975). Empirical evidence for the crucial role of foreign experience is found, for example, in Davidson (1980). We thus formulate the following hypotheses:

H2a: The likelihood that a firm currently has FDI activities in a certain region is particularly high if it has long-standing FDI experience.

H2b: Early FDI experience increases the probability that a firm invests in regions whose characteristics are dissimilar to those of Switzerland (primarily Eastern Europe, Latin America, Asia). Accordingly, the effect of FDI experience on the likelihood of FDI is larger for such dissimilar regions, if we compare the experience effects across regions.

\section{Potential for innovation}

Knowledge acquisition is a further important factor that drives FDI. Innovativeness is an important firm-specific characteristic that determines, among other things, the firms' propensity to invest in foreign locations (“ownership advantage"; see, e.g., Dunning 2000). In addition, innovative firms especially from small countries are likely to seek abroad for additional or complementary know-how (see, among many others, Le Bas \& Sierra 2002), since its domestic knowledge base is mostly limited and/or highly specialized. Hence, we expect that the most advanced countries with high potential for innovation would be

\footnotetext{
${ }^{4}$ The distance-related cost savings in case of production-oriented FDI relative to those of distribution-oriented FDI are particularly high for FDI in knowledge-intensive industries (see Keller \& Yeaple 2009) whose share in Swiss exports and FDI is very high.
} 
partikcularly attractive locations for "knowledge-seeking FDI" (see Blonigen 2005; Kogut \& Chang 1991).

As a consequence, we postulate the following hypothesis:

H3a: The likelihood that a firm currently has FDI activities in a certain region is larger for firms with innovation activities at home than for those without such activities, if we compare firms with FDI in the same host region.

The low production costs of less developed countries primarily attract less innovative firms. Knowledge seeking in combination with innovation-based $\mathrm{O}$-advantages should thus lead to a higher share of innovative firms with FDI activities in developed than in less developed host regions. The respective hypothesis is as follows:

H3b: Innovative firms are more prone to locate FDI in regions with a favorable innovation environment (many innovative firms; presence of top-level universities, etc.) such as North America and EU15/EFTA. We thus expect that the innovation effect is largest for these regions.

\section{Data}

The firm data used in this investigation have been collected in the course of a postal survey on the "Internationalization of the Swiss Economy" carried out in spring 2010. The available data are to a high extent qualitative in nature (nominal or ordinal measures). The survey yielded information on international activities differentiated by type (exports, licensing, etc. as well as FDI related to distribution, production, R\&D, etc.), degree of ownership control (wholly-owned affiliate, joint venture, etc.), regional orientation of FDI, motives for and obstacles to FDI, type and extent of the (two-way) trade flows between parent companies and their foreign subsidiaries, etc. In addition, we collected information about innovative activities and some basic characteristics of the firm (sales, value added, employment, firm age, industry affiliation, etc). ${ }^{5}$

The questionnaire has been addressed to a sample of about 4500 firms (with at least five employees) covering the business sector (i.e. including services) of the Swiss economy. The sample has been (disproportionally) stratified by 29 industries and three industry-specific firm size classes (with full coverage of large companies). The survey yielded valid information for 1921 enterprises, implying a response rate of $42 \%$, what is satisfactory given the very demanding questionnaire. The structure of the responding firms in terms of size and industry

\footnotetext{
${ }^{5}$ The questionnaire is available in German, French and Italian on www.kof.ethz.ch/en/surveys/structuralsurveys/other-surveys/survey-internationalisation-swiss-economy-2010/.
} 
affiliation is quite similar to that of the underlying sample. 545 firms areengaged in FDI (about $28 \%$ of all valid responses). Depending on the number of missing values of the explanatory variables that differs considerably across the estimated models (see below) 334 to 473 observations could be used to analyze econometrically the factors determining the choice of host regions of FDI.

\section{Empirical test of hypotheses}

\section{Operationalization of hypotheses}

Hypothesis 1 focuses on the differentiation between vertical (production-oriented) FDI, horizontal (production-oriented) FDI and distribution-oriented FDI. Hypothesis 1 is tested using three different types of indicators. A first variable measures the change of the parent firms' employment in Switzerland in the upswing period 2003-2008. Since vertical FDI involve the relocation of parts of the supply chain, this type of FDI implies as a direct effect a reduction of the domestic employment of the parent company. ${ }^{6}$ Therefore, in line with H1, we expect that parent firms having invested in Eastern Europe, Latin America and Asia, respectively, recorded a decrease of employment or a weaker growth of employment in the reference period than those with FDI in other regions.

A second measure we use to represent the three types of FDI is based on the intensity of the two-way trade flows of goods/services between the parent company and its foreign subsidiaries (intra-firm trade flows). As distribution-oriented FDI are associated with large outflows of products to the foreign sales market, we expect considerable net outflows to regions where this type of FDI is predominant. On the other hand, we should observe net inflows from regions that primarily are destinations of vertical FDI (intra-firm deliveries of primary and intermediate products to the parent company). In case of horizontal FDI, we expect neither substantial outflows nor inflows since production takes place locally. Accordingly, trade inflows from regions hosting horizontal FDI should be smaller than outflows to countries having received vertical FDI. Finally, we expect that outflows to host regions of horizontal FDI are smaller than outflows to locations having attracted predominantly distribution-oriented FDI.

\footnotetext{
${ }^{6}$ In the longer run, the relocation of certain parts of the supply chain abroad may also improve the competitiveness of a firm, leading to an increase of jobs in Switzerland (indirect effect). However, we presume that, on balance, the negative employment effect weighs more.
} 
The third measure focuses on production-oriented FDI. Based on the sub-sample of firms engaged in this type of FDI, we analyze the probability of a firm locating its production facilities in a certain region. To this end we exploit data on the firms' motives for establishing (or extending) production sites in foreign locations that allow us to distinguish between "costrelated" and "market-related" motives. Examples of the latter are "market expansion", "early market presence to gain a competitive advantage" or "following customers by establishing production facilities abroad". Cost-oriented motives are, for example, "lower labor costs", "more flexible labor market regulations", "tax advantages" or "less strict environmental laws" in host regions as compared with Switzerland. We expect that horizontal FDI are driven by market-related motives, whereas cost-oriented motives dominate in regions hosting vertical FDI.

Hypothesis 2 emphasizes the impact of FDI experience. Our dataset contains information on the period of the first-time FDI activity and the age of firms. First-time presence is used as a direct measure of FDI experience, whereas firm age indirectly captures FDI experience as it is expected to correlate positively with industry and export experience.

Hypothesis 3 deals with a firm's innovation activities. In line with previous literature (see Kogut \& Chang 1991) the innovation potential of an MNE is captured by variables measuring the domestic innovation intensity of the parent company. Innovation intensity is captured by (a) the share of $R \& D$ activities in total sales (R\&D intensity) and (b) the share of employees with a tertiary-level degree (human capital intensity).

\section{Econometric framework}

The dependent variable is a dummy variable that takes the value one for MNEs with subsidiaries in a certain region and value zero otherwise (for a detailed definition of all variables see Table 2; the descriptive statistics are shown in Table A.1 in the appendix). Due to the fact that many parent companies invest at the same time in several host regions, we presumed that the decisions on FDI locations are correlated. This was confirmed by LR-tests of the multivariate probit against independent univariate probits for all models we estimated. The residuals of the dependent variables of the different models were thus not independent of each other. To take account of such interdependencies we tried to estimate a multivariate probit model for all nine host regions. As the model did not converge, when we included all nine FDI host regions at ones, we chose a two-step approach. In a first step, we estimated a multivariate probit model for the five "main regions" as defined in Section 4 (EU/EFTA, North America, Latin America, Eastern Europe, Asia). In a second step, we captured, where 
necessary, differences between sub-regions by estimating a multivariate probit model separately for the three sub-regions of the main regions "Eastern Europe" ( "Eastern Europe" in the narrow sense, "Southeast Europe" and "Russia") and Asia ("China", "Asian Tigers" and "Southeast Asia/India").

As some of the model variables are not available for firms without FDI, we had to restrict the estimation sample to firms having invested abroad. As a consequence, we assumed that a firm's location choice is taken independently of its general FDI decision. Therefore, focusing on FDI performing firms should not affect the estimation results. Nevertheless we tested for a potential selection bias. By applying the STATA heckprob procedure, we separately tested for each of the five "main regions" whether the firms' general FDI decision does affect its location choice. ${ }^{7}$ As the LR tests of independent equations were statistically insignificant for each region, there is no evidence for a selection bias, and we conclude that focusing on firms with FDI activities is an adequate procedure.

\section{Specification of three empirical models}

We estimated three different models which share the variables representing FDI experience and innovation input but differ with respect to the variables reflecting the effects of the FDI type (employment growth, intensity of intra-firm trade, motives for "production-oriented" FDI). Model I ("Basic Model”) contains (in addition to FDI experience, innovation input and some general controls) only the variable measuring employment growth in order to be able to exploit the maximum of available data (473 observations). Due to differing numbers of missing values we had to estimate separately Model II (adding the variables for intra-firm trade, thus using only 334 observations) and Model III (using the variables representing the motives for production-oriented FDI instead of the variables capturing intra-firm trade, thus reducing the sample to 371 observations). ${ }^{8}$

\footnotetext{
${ }^{7}$ The selection equation of the Heckman model is specified in the same way as the outcome equation, with the exception of the additional identifying variable that is not in the outcome equation. To identify the Heckman model, instrument variables are added to the selection equations. The instruments are industry averages of variables that measure the firms' demand development. We assume that these industry variables pick-up the effect of unobserved industry-specific attributes that contribute to the potential endogenous firm-specific variables (see, e.g., Cassiman \& Veugelers 2002, p. 1174 for a similar justification of the use of industry variables as instruments). Accordingly, it can be assumed that these instruments are uncorrelated with the error term. Furthermore, all instruments are correlated with the dependent variable in the selection equation (FDI yes/no) but uncorrelated with the dependent variable in the outcome equation (location choice). As information on specific FDI characteristics of the firms (e.g., on FDI experience or trade flows) is only available for firms with FDI activities, we could not include these variables in our selection model. The detailed estimation results are available on request.

${ }^{8}$ The correlation between employment growth and the flow variables for intra-firm trade is about 0.15 , between employment growth and the motive variables about 0.12 . Thus, there is no issue of multicollinearity if both variables are used in the same model. However, the flow variables and the motive variables (particularly the
} 
Model I includes two explanatory variables describing the parent firm's FDI experience (first_fdi; firm_age), two types of innovation input ( $r \& d \_i n t e n s i t y$, tertiary_share) and the change of domestic employment of the parent firm in the upswing period 2003-2008 (employment_growth). Furthermore, we control for firm size (size) and industry affiliation (industry).

In Model II, we investigated the effect of the intensity of the two-way trade flows between the parent company and its foreign subsidiaries on the selection of FDI host regions. To this end we used the variable inflow measuring the intensity of flows of goods/services from foreign subsidiaries to the parent company in Switzerland, whereas outflow represents the intensity of flows in the opposite direction. Apart from that we inserted the variables contained in Model I.

Finally, in Model III we analyzed whether the motives for production-oriented FDI differ among regions. The respective data refer to 20 single motives, the importance of which has been assessed by the firms on a five-point Likert scale. Using principal component factor analysis of the single motives, we identified four groups of motives for production-oriented FDI (see Table A.3 in the appendix for detailed information on the individual motives and the factor pattern matrix). Factor 1 stands for sales-oriented motives (sales_motive), whereas the factors 2 to 4 refer to three types of cost-oriented motives: Factor 2 captures the institutional conditions in the host regions (institutional_motive) such as less restrictive environmental laws or more flexible labor market regulations as compared with Switzerland. Factor 3 depicts advantages of the host regions with respect to production costs (production_cost_motive); finally, factor 4 represents the host countries' advantages with respect to the availability of certain input factors (input_motive) such as natural resources or labour. The four "motive variables" extracted by factor analysis are added to the explanatory variables used in Model I whereas the specific variables of Model II, i.e. those measuring the intra-firm trade flows (inflow and outflow) were dropped.

The analysis, as most studies in this field of research, is based on cross-sectional data (see Section 4). Therefore, the potential problem of endogeneity cannot be solved. As a consequence, tone should be cautious in interpreting the results. Hence we refrain from making causal claims, but rather interpret the estimated coefficients as partial correlations. Nevertheless these show whether and to what extent the results are in line with the hypotheses postulated in Section 3.

inflow variable and the production cost motive variable) are strongly correlated. To avoid this multicollinearity problem, the two groups of variables are thus estimated in separate models. 


\section{Estimation results}

\subsection{Model I: Basic model}

Results for Model I are presented in Table 3. Columns (1) to (5) show the results for the five main regions. Columns (6) to (8) and (9) to (10), respectively, contain the findings for the same model but for the sub-regions of the two aggregated regions. In case of Model I, the estimation results for the sub-regions of Eastern Europe as well as those for Asia are more or less the same as for the corresponding aggregated regions. Therefore, in analyzing the results of Model I, we focus on differences among the five main regions.

\subsubsection{Vertical versus horizontal FDI}

Results for the variable "employment_growth" (referring to the 1990s) provide some first evidence with respect to hypothesis H1. It turns out that domestic employment growth of firms having FDI at locations in the regions Eastern Europe and Asia is significantly smaller than for companies with FDI in EU15/EFTA and, to a lesser extent, North America. Hence, FDI in the former two regions serve to relocate some parts of the supply chain ("vertical FDI"), what is in line with H1. Surprisingly, employment growth of Swiss parent companies with FDI in Latin America is not significantly smaller than that of firms with FDI in Western countries. This may be due to the fact that the average size of the company group (parent firm and all its affiliates) is much larger in case of firms with FDI in Latin America than for those having invested elsewhere. ${ }^{9}$ Accordingly, it seems plausible that primarily a global presence, and not the relocation of employees, motivates the firms to directly invest in this region.

\subsubsection{FDI experience}

In line with hypothesis $\mathrm{H} 2 \mathrm{a}$, the probability that a firm has FDI activities in a certain region is significantly higher for firms that already had FDI activities before 1990 (first_fdi_1990) than for companies that have invested abroad only after 2000 (within region comparisons). Furthermore, this effect increases with the extent of FDI experience as, for each region, the coefficient of first_fdi_1990 is significantly larger than that of first_fdi_2000.

On the whole, the findings referring to the differences across regions are not consistent with hypothesis $\mathrm{H} 2 \mathrm{~b}$. The coefficients of first_fdi_1990 and first_fdi_2000 estimated for EU15/EFTA, North America and Asia are significantly larger than those we found for Eastern Europe and Latin America (confirmed by Wald tests on the equality of coefficients across region-specific equations). Contrary to our hypothesis, less experienced firms have a higher

\footnotetext{
${ }^{9}$ Average employment of the company group with FDI in the EU15/EFTA is 2948, in Eastern Europe 4274, in North America 4865, in Asia 4135 and in Latin America 7039.
} 
probability to invest in the more dissimilar regions Eastern Europe and Latin America than in the more similar regions EU15/EFTA and North America. Accordingly, FDI experience seems to affect primarily the extent of coverage of FDI host regions (number of regions where a firm is present) rather than the choice of a specific FDI location itself.

The coefficients of firm age (firm_age), our second measure of FDI experience, are insignificant for all target regions. Industry and export experience that are associated with this variable do not seem to affect the choice of locations of FDI.

\subsubsection{Potential for innovation}

In most regions, highly innovative parent firms (measured by $r \& d \_$intensity and tertiary_share) are more likely to invest than non-innovative firms, what is in line with hypothesis $\mathrm{H} 3 \mathrm{a}$. In less developed regions this is the case because of $\mathrm{O}$-advantages of the parent firms; in North America, among other things, because of its attractiveness for knowledge-seeking FDI. In contrast to H3a, innovative parent firms do not invest more often in EU15/EFTA than other firms.

Hypothesis $\mathrm{H} 3 \mathrm{~b}$ is only partly confirmed by the estimates. As expected, the coefficients of the two innovation input variables ( $r \& d$ intensity, tertiary_share) are larger for North America than those for the less developed region Eastern Europe. However, contrary to our expectations, this is not the case for the regions Latin America and Asia and, again in contrast to $\mathrm{H} 3 \mathrm{~b}$, the innovation potential of firms has a significantly smaller impact on the likelihood of FDI in EU15/EFTA. Overall, the evidence for H3b is quite weak.

\section{Additional evidence: descriptive analysis of domestic and foreign $R \& D$ activities}

As these results are surprising, we looked at the matter in some more detail by way of a descriptive analysis of domestic and foreign R\&D activities of Swiss firms, differentiating by host regions of FDI. The results are presented in Table 4. The data shown in the first row of the table reveal that the share of R\&D performing parent firms varies across FDI host regions more or less in the same way as the coefficients found for $r \& d$ intensity in the model estimates (for example, North America high share and statistically significant coefficient, EU15/EFTA low share and insignificant coefficient). In case of EU15/EFTA, not less than $30 \%$ of firms without own R\&D are present with FDI in this region because of its relative attractiveness for distribution-oriented FDI (see the estimates for Model II in subsection 6.2) as well as for reasons not explicitly accounted for in the model (e.g. historical ties, geographic and cultural proximity, etc). These effects seem to be much stronger than that of the high innovation potential of locations in EU15/EFTA. 
The second row shows, in line with H3b, that foreign affiliates in EU15/EFTA and North America have much more often local R\&D activities than those present in Latin America and Eastern Europe.

China is the only country that does not fit the pattern observed for the less advanced regions as described in $\mathrm{H} 3 \mathrm{~b}$. There are probably two explanations for this result. Firstly, most FDI in Chinese R\&D centers are concentrated in Beijing and Shanghai that have a welldeveloped infrastructure, highly qualified human resources and some top-class universities (see Gassmann \& Han 2004). Hence the innovation environment of China as a whole is not representative for the economic core regions of this country (what to some extent is also true for India). Besides, the quite impressive R\&D activity of local affiliates may also reflect the policy of Chinese authorities pushing foreign firms to transfer their technology.

The most important reason for the unexpected results with respect to $\mathrm{H} 3 \mathrm{~b}$ is probably the low correlation between the firms' propensity to perform R\&D at home and to invest abroad in such activities (row 3 of Table 4). The respective correlation coefficient is lower than 0.2 for all regions, with the exception of EU15/EFTA (0.36).

To sum up, Table 4 allows us to distinguish three types of regions representing different combinations of domestic and foreign R\&D. Firstly, EU15/EFTA attracts a much higher percentage of Swiss firms that are not active in R\&D. However, as EU15/EFTA denotes a significantly higher correlation between $R \& D$ activities at home and abroad than the other regions, a much higher percentage of R\&D-performing parent companies also invest locally in such activities. Secondly, North America and Asia (for example China) typically host affiliates of R\&D-performing parent firms, a significant percentage of which are active in R\&D also locally. Thirdly, in case of FDI in Latin America and Eastern Europe (most accentuated in Southeast Europe and Russia) R\&D activities remain primarily located in Switzerland.

\subsection{Model II: Intra-firm trade flows}

Table 5 shows the results for Model II that extends Model I by including the trade flow variables (inflow, outflow) that reveal the role of different types of FDI in more detail. The intensity of trade flows from the foreign affiliates to their parent company in Switzerland (inflow) is significantly larger for firms with FDI in Eastern Europe or Asia (to a lesser extent also in Latin America) than for companies that invested in EU15/EFTA or North America. If we take account only of statistically significant differences of the coefficients of inflow, we get the following pattern: $($ Eastern Europe $=$ Asia $)>$ Latin America $>($ EU15/EFTA $=$ North 
America). On the other hand, the flows from the parent companies to their foreign subsidiaries (outflow) are significantly larger for EU15/EFTA, North America and Eastern Europe, respectively, than for the other regions. Furthermore, outflows to the EU15/EFTA are significantly larger than those to North America, and they also tend to be larger than the deliveries to foreign subsidiaries in Eastern Europe. In sum, the differences in size among the coefficients of outflow show the following pattern: EU15/EFTA $>$ (Eastern Europe $=$ North America $)>($ Latin America $=$ Asia $)$.

Thus, in accordance with hypothesis H1, we can observe small inflows and large outflows for the region EU15/EFTA, which is evidence for distribution-oriented FDI. Trade inflows from North America are also small, but trade outflows are clearly not as large as those to EU15/EFTA. We may thus conclude that horizontal FDI is, as expected, more common in North America than in EU15/EFTA. Hypothesis H1 receives further support by the fact that FDI in Asia is of the vertical type, characterized by large trade inflows and small trade outflows. FDI in Eastern Europe and Latin America also seem to be of the vertical type (larger coefficient for trade inflows than outflows). However, this conclusion has to be qualified. Rather unexpected, trade outflows are relatively large in case of Eastern Europe. It seems that Eastern Europe, as a result of the strong economic growth achieved in recent years and in view of the short distance to Switzerland, has been discovered by Swiss firms not only as a favorable location for manufacturing ("vertical FDI") but to some extent also as a promising market for their products ("distribution FDI"). The second qualification refers to Latin America as we observe that trade flows in both directions are smaller than those of Eastern Europe and - less accentuated - those of Asia. Thus, subsidiaries in Latin America seem to be less dependent from their parent companies than foreign affiliates in other regions with vertical FDI; this result is in line with what we found for the variable employment_growth. ${ }^{10}$

Columns (6) to (8) and (9) to (10) of Table 5 contain the findings for Model II for the subregions of Eastern Europe and Asia. Disaggregation does not much affect the results for Eastern Europe. In accordance with the results for the aggregated region, large trade inflows (inflow) as well as large trade outflows (outflow) characterize all three sub-regions. More heterogeneous are the results we find for the Asian sub-regions. Whereas the propensity to invest in China or in Southeast Asia/India is positively correlated with the intensity of trade inflows (inflow), the propensity to have FDI in the tiger countries is positively correlated with

\footnotetext{
${ }^{10}$ FDI activities in Latin America do not affect employment growth of the parent company in Switzerland.
} 
the intensity of trade outflows (outflow). The differences between the Asian sub-regions discussed in Section 2 thus seem to have consequences for the type of FDI. The relatively rich tiger countries primarily attract distribution-oriented FDI, the low wage costs in the two other Asian sub-regions lead, in the first place, to vertical FDI.

\subsection{Model III: Motives for production-oriented FDI}

Model III analyzes production-oriented FDI in more detail, in order to get some more insight into the variation across host regions by type of FDI (Table 6). In doing so, we focus on the distinction between regions with vertical FDI and regions with horizontal FDI. In line with hypothesis H1, cost motives (production_cost_motive) are of low relevance for productionoriented FDI in the EU15/EFTA region and in North America. Production in North America is primarily driven by sales-oriented motives (sales_motive) and, rather surprisingly, the local institutional conditions. However, the latter result becomes plausible when we look more closely to the single motives covered by the (aggregate) variable institutional_motive. The significant effect of this measure is exclusively due to the richer endowment with highly qualified employees in North America as compared with Switzerland.

Hypothesis $\mathrm{H} 1$ is further confirmed by the fact that cost motives are primarily relevant for production in Eastern Europe and Asia, which is additional evidence for vertical FDI in these regions. However, the results also show that a clear distinction between horizontal and vertical FDI is not possible for these regions, as production is also motivated by local sales. While the local market in Asia is primarily served by local production (Model II: small trade outflows), the market in Eastern Europe is served by local production as well as distribution of products exported from Switzerland (Model II: intermediate size of trade outflows). This is intuitively plausible as the average purchasing power is much lower in Asia. Hence, production costs are more important in case of Asia than of Eastern Europe; consequently, the sales of products primarily stem from local production. The large distance to Asia is another factor favouring sales out of local production.

In case of Asia, we get a clearer picture by analyzing the motives at a more disaggregated level. Similar to Model II, we find evidence for vertical FDI in case of Southeast Asia/India (production_cost_motive is dominant). Production in the tiger countries is primarily of the horizontal type (sales_motive is dominant). For China, we observe a mix of horizontal and vertical FDI. In view of the large size and the high growth (potential) of the Chinese market it is not surprising that market-oriented motives are highly important as well. 
The drivers of production-oriented FDI in Latin America are unclear. Neither production costs nor sales motives appear to affect significantly the propensity of production-oriented FDI in this region. However, the fact that low production costs are significantly more important as a motive for FDI in Latin America than in the regions EU15/EFTA and North America indicates a certain relevance of vertical FDI.

\section{Conclusions}

In this paper we aim at explaining the choice of foreign locations of Swiss MNEs. In doing so we distinguish nine host regions exhibiting specific characteristics that received more than 95\% of Swiss outward FDI. We distinguish at firm level three categories of explanatory variables that measure (a) the type of FDI (vertical, horizontal, distribution-oriented), (b) FDI experience, and (c) the potential for innovation. The model estimates are interpreted in the light of some characteristics of the host regions that are relevant for the analysis at hand (level of wage cost, per capita national income, innovation capacity, etc). The paper draws on crosssection data stemming from a survey conducted in the year 2010. Since firms may be present in several countries, model estimations are based on the multivariate probit procedure.

Overall, the models used to determine the relationship between the type of FDI and the choice of the host region yielded the expected results. In case of the economically less advanced target regions, the results are more differentiated than we hypothesized. However, this is primarily due to the heterogeneity of these regions; the results for the sub-regions are highly plausible and largely correspond to the considerations underlying our hypotheses. The estimates based on three categories of explanatory variables representing the types of FDI show that North America and EU15/EFTA are more likely than other regions to host FDI of the horizontal type (small trade inflows from the affiliates to the parent company; higher employment_growth in Switzerland; production_cost_motive of low importance). As expected trade outflows to affiliates located in EU15/EFTA region are significantly larger than trade outflows to North America, what is an indication for distribution-oriented FDI. Turning to the less advanced host regions, we find, in accordance with our hypothesis, that Eastern Europe primarily receives vertical FDI. However, the pattern of the results also points to some relevance of distribution-oriented FDI (quite large outflows) and horizontal FDI (relevance of the sales_motive). Obviously, Eastern Europe is not only a location for (cheap) production. FDI in this region is, to some extent, also a means to exploit the potential of this (strongly) growing regional market. Asia as a whole seems to attract, as expected, primarily vertical 
FDI. However, there are large differences among the three sub-regions. It is not surprising (and is consistent with our model) that horizontal FDI is more common in the already highly developed tiger countries (large trade outflows; high relevance of the sales_motive), whereas FDI in Southeast Asia/India is mostly of the vertical type (large inflows; high importance of the production_cost_motive). Interestingly, in case of China we find a mix of both vertical FDI (large inflows; high relevance of the production_cost_motive) and horizontal FDI (high importance of the sales_motive). In other words, the fast-growing Chinese economy is not only a cheap location for manufacturing but also a significant host country of market-oriented FDI. In case of Latin America there are some indications of vertical FDI (trade inflow surplus), but the investment motives do not convey a clear picture. Compared with other regions with vertical FDI the subsidiaries in this region seem to be more independent from their parent company in Switzerland (lower trade inflows; higher employment_growth in Switzerland).

The second group of explanatory variables pertaining to FDI experience primarily seems to affect the level of global expansion of the Swiss MNEs rather then, as we hypothesized, the selection of a specific location.

Finally, we found that the probability that a firm has currently FDI activities in a certain region is positively correlated with its innovation activities at home (with the exception of the EU15/EFTA region). However, the innovation potential of the host region is not a decisive factor for attracting FDI of innovative parent companies (with the exception of North America). In general, the correlation between innovative activities of the parent company in Switzerland and the location of foreign subsidiaries is low. The share of foreign affiliates with parent companies that have a high innovative potential is at lowest for subsidiaries in the EU15/EFTA. However, innovation activities abroad are more common in the regions EU15/EFTA, North America and Asia (for example China), than in Eastern Europe and Latin America.

In conclusion, the study shows that an analysis of outward FDI using detailed information on parent companies, their affiliates and the intra-firm trade of goods and services as well as on some characteristics of host regions can significantly contribute to a better understanding of the MNEs' choice among alternative foreign locations. The analysis clearly goes beyond previous microeconometric work in terms of the breadth of included firm characteristics as well as the estimation method. Nevertheless, it has become obvious that future research requires more informative data. Essential is, firstly, more comprehensive information on structure and activities of the parent company and the affiliates (including in case of MNEs 
with several affiliates the role of the various units of the company group). Secondly, quantitative data at firm-level could open up new possibilities of empirical research on this topic. Finally, longitudinal data, so far not used in firm-level investigations, would be a great leap forward as they are a precondition for (a) analyzing the dynamics of the choice of foreign locations, and (b) identifying causal links what is not feasible in the frame of a cross-section analysis such as that presented in this paper.

\section{References}

Aulakh, P.S. and H. Teegen (2000). Export Strategies and Performance of Firms from Emerging Economies: Evidence from Brazil, Chile, and Mexico, Academy of Management Journal, 43(3): 342-361.

Aw, B.Y. and Y. Lee (2008). Firm Heterogeneity and Location Choice of Taiwanese Multinationals, Journal of International Economics, 75(1): 167-179.

Barrios, S., Gorg, H. and E. Strobl (2006). Multinationals' location choice, agglomeration economies and public incentives, International Regional Science Review, 29(1): 81-107.

Basile, R., Castellani, D. and A. Zanfei (2008). Location choice of multinational firms in Europe: The role of EU cohesion policy, Journal of International Economics, 74(2): 328340.

Beamish, P.W. and A. Delios (2001). Japanese Investment in Transitional Economies: Characteristics and Performance. In D. Denison (Ed.), Managing Organizational Change in Transition Economies, Mahwah, NJ: Lawrence Erlbaum Associates.

Blonigen, B.A. (2005). A Review of the Empirical Literature on FDI Determinants, Atlantic Economic Journal, 33(4): 383-403.

Blonigen, B.A. and M. Wang (2005). Inappropriate Pooling of Wealthy and Poor Countries in Empirical FDI Studies, in T. Moran, E. Graham and M. Blomstrom (Eds.), Does Foreign Direct Investment Promote Development? Washington, DC: Institute for International Economics, 221-243.

Brainard, S.L. (1993). An Empirical Assessment of the Factor Proportions Explanation of Multi-National Sales, NBER Working Papers 4583, National Bureau of Economic Research, Cambridge (MA).

Brainard, S.L. (1997). An Empirical Assessment of the Proximity-Concentration Tradeoff between Multinational Sales and Trade, American Economic Review, 87(4): 520-544.

Cantwell, J. (2008). Location and the Multinational Enterprise, Journal of International Business Studies, 40(1): 35-41. 
Cassiman, B. and R. Veugelers (2002). R\&D Cooperation and Spillovers: Some Empirical Evidence from Belgium, American Economic Review, 92(4): 1169-1184.

Caves, R.E. (1982). Multinational Enterprise and Economic Analysis, Cambridge: Cambridge University Press.

CEPII (2010). CEPII Geographic Data, available at: www.cepii.fr/anglaisgraph/bdd/ distances.htm (accessed 28 September 2011).

Chen, M.X. and M.O. Moore (2010). Location Decisions of Heterogeneous Multinational Firms, Journal of International Economics, 80: 188-199.

Davidson, W.H. (1980). The Location of Foreign Direct Investment Activity: Country Characteristics and Experience Effects, Journal of International Business Studies, 11(2): $9-22$.

Demirbag, M. and K.W. Glaister (2010). Factors Determining Offshore Location Choice for R\&D Projects: A Comparative Study of Developed and Emerging Regions, Journal of Management Studies, 47: 1534-1561.

Dunning, J.H. (1993). Multinational Enterprises and the Global Economy, Workingham: Addison-Wesley.

Dunning, J.H. (1998). Location and the Multinational Enterprise: A Neglected Factor? Journal of International Business Studies, 29(1): 45-66.

Dunning, J.H. (2000). The Eclectic Paradigm as an Envelope for Economic and Business Theories of MNE Activity, International Business Review, 9(2): 163-190.

Dunning, J.H. and S.M. Lundan (2008). Multinational Enterprises and the Global Economy. Second Edition, Cheltenham: Elgar.

Eaton, J. and A. Tamura (1994). Bilateralism and Regionalism in Japanese and US trade and Foreign Direct Investment Relationships, Journal of Japanese and International Economics, 8: 478-510.

Ekholm, K. (1998). Proximity Advantages, Scale Economies, and the Location of Production. In P. Braunerhjelm and K. Ekholm (eds), The Geography of Multinationals, Dordrecht: Kluwer Academic.

Gassmann, O. and Z. Han (2004). Motivations and Barriers of Foreign R\&D Activities in China, $R \& D$ Management, 34(4): 423-437.

Guimaraes, P., Figueiredo, O. and D. Woodward (2000). Agglomeration and the location of foreign direct investment in Portugal, Journal of Urban Economics, 47(1): 115-135. 
Hanson, G.H., Mataloni, R.J. and M.J. Slaughter (2001). Expansion Strategies of U.S. Multinational Firms, in D. Rodrik and S. Collins (Eds.), Brookings Trade Forum, 245294.

Hymer, S. (1976). The International Operations of National Firms: A Study of Direct Foreign Investment, Cambridge (MA): MIT Press.

Hattari, R. and R.S. Rajan (2009). Understanding Bilateral FDI Flows in Developing Asia, Asian-Pacific Economic Literature, 23(2): 73-93.

Johanson, J. and J.E. Vahlne (1977). The Internationalization Process of the Firm: A Model of Knowledge Development and Increasing Foreign Market Commitments, Journal of International Business Studies, 8(1): 23-32.

Johanson, J. and F. Wiedersheim-Paul (1975). The Internationalization of the Firm: Four Swedish Case Studies, Journal of Management Studies, 12(3): 305-322.

Keller, W. and S.R. Yeaple (2009). Gravity in the Weightless Economy, NBER Working Papers 8433, National Bureau of Economic Research, Cambridge (MA).

Kogut, B. and S.J. Chang (1991). Technological capabilities and Japanese direct investment in the United States, Review of Economics and Statistics, 73(3): 401-13.

Le Bas, C. and C. Sierra (2002). Location vs. Country Advantages in R\&D Activities : Some Further Results on Multinationals' Location Strategies, Research Policy, 31(4): 589-609.

Makino, S., Beamish, P.W. and N.B. Zhao (2004). The Characteristics and Performance of Japanese FDI in Less Developed and Developed Countries, Journal of World Business, 39(4): 377-392.

Mody, A., Razin, A. and E. Sadka (2003). The Role of Information in Driving FDI Flows: Host-Country Tranparency and Source Country Specialization, NBER Working Papers 9662, National Bureau of Economic Research, Cambridge (MA).

Nachum. K., Zaheer, S. and S. Gross (2008). Does It Matter Where Countries Are? Proximity to Knowledge, Markets and Resources, and MNE Location Choices, Management Science, 54, 2008, 1252-1265.

Py, L. and F. Hatem (2009). Internationalization and Location of Services: a Sectoral and Functional Analysis Applied to Multinational Firms in Europe, Économie et Statistique, 426: 67-95.

Shatz, H.J. and A.J. Venables (2000). The Geography of International Investment, Policy Research Working Paper Series 2338, The World Bank.

SNB (2011). Kapitalbestand von Schweizer Direktinvestitionen im Ausland 2008, available at: www.snb.ch/de/iabout/stat/statpub/fdi/stats/fdi (accessed 25 September 2011). 
Teece, D.J., Pisano, G. and A. Shuen (1997). Dynamic Capabilities and Strategic Management, Strategic Management Journal, 18: 509-533.

Transparency International (2008). TI Corruption Perceptions Index 2008, available at: www.transparency.org/policy_research/surveys_indices/cpi/2008 (accessed 28 September 2011).

UBS (2009). Prices and Earnings 2009, available at: www.ubs.com/1/e/wealthmanagement/ wealth_management_research/prices_earnings (accessed 28 September 2011).

World Salaries (2005). International Average Employment Income Comparison, available at: www.worldsalaries.org/employment-income.shtml (accessed 28 September 2011).

Worldbank (2010). World Development Indicators (WDI) and Global Development Finance (GDF), available at: databank.worldbank.org (accessed 28 September2011). 
Table 1: Characteristics of the regions

\begin{tabular}{|c|c|c|c|c|c|c|c|c|c|c|c|c|c|c|c|}
\hline \multirow[b]{2}{*}{ Indicator } & \multicolumn{3}{|c|}{ EU15/EFTA } & \multicolumn{3}{|c|}{ Eastern Europe } & \multicolumn{3}{|c|}{ Latin America } & \multicolumn{3}{|c|}{ Asia } & \multicolumn{2}{|c|}{$\begin{array}{c}\text { North } \\
\text { America }\end{array}$} & \multirow{2}{*}{$\begin{array}{c}\text { Switzerland } \\
\mathrm{CH}\end{array}$} \\
\hline & GER & UK & FRA & POL & RUS & CZE & BRA & MEX & VEN & SGP & $\mathrm{CHN}$ & IND & CAN & USA & \\
\hline \multicolumn{16}{|l|}{ Intensity of FDI activities } \\
\hline Share of capital stock of Swiss FDI abroad & 6.9 & 6.3 & 4.4 & 0.6 & 0.7 & 0.4 & 4.1 & 0.7 & 0.2 & 1.0 & 0.8 & 0.7 & 4.0 & 18.5 & \\
\hline \multicolumn{16}{|l|}{ Purchasing power } \\
\hline $\begin{array}{l}\text { GNI per capita, PPP (current international \$) } \\
\text { Household final consumption expenditure per capita (constant } 2000\end{array}$ & 35950 & 36240 & 33280 & 16710 & 15460 & 22890 & 10080 & 14340 & 12850 & 47970 & 6010 & 3600 & 38710 & 46790 & 39210 \\
\hline US\$) & 13926 & 19400 & 13761 & 3801 & 1877 & 3811 & 2904 & 4762 & 4096 & 9725 & 727 & 622 & 15503 & 27378 & 21950 \\
\hline \multicolumn{16}{|l|}{ Growth of purchasing power } \\
\hline 5-year GDP per capita growth (\% 2003-2008; constant 2000 US\$) & 9.5 & 8.5 & 5.9 & 30.1 & 42.8 & 26.3 & 19.1 & 12.2 & 50.4 & 18.1 & 62.5 & 24.1 & 7.3 & 7.3 & 9.7 \\
\hline Household final consumption expenditure per capita growth (annual \%) & 0.1 & 1.4 & 1.0 & 5.4 & 11.4 & 3.6 & 7.8 & 1.3 & 7.1 & & 8.2 & 5.3 & 4.5 & 2.7 & 2.1 \\
\hline \multicolumn{16}{|l|}{ Wage costs } \\
\hline Gross hourly pay in a big city (current US\$/hour) & 23.0 & 18.0 & 18.0 & 5.6 & 6.9 & 6.5 & 5.6 & 2.1 & 5.2 & 7.1 & 3.9 & 1.6 & 17.1 & 26.1 & 30.3 \\
\hline Annual gross employment income per worker (current US\$) & 36444 & 34854 & & & 11378 & 13020 & 9801 & 6143 & & 23972 & 4397 & & & 42028 & 35307 \\
\hline \multicolumn{16}{|l|}{ Innovative potential } \\
\hline Labor force with tertiary education ( $\%$ of total) & 24 & 32 & 29 & 22 & 53 & 14 & 9 & 17 & - & 24 & - & 7 & 46 & 61 & 30 \\
\hline Research and development expenditures (\% of GDP) & 2.6 & 1.8 & 2.1 & 0.6 & 1.1 & 1.6 & 1.0 & 0.5 & - & 2.6 & 1.5 & 0.0 & 2.0 & 2.7 & 2.9 \\
\hline Researchers in R\&D (per million people) & 3453 & 2881 & 3440 & 1610 & 3305 & 2715 & 629 & 460 & - & 6088 & 1071 & 205 & 4157 & 4663 & 3436 \\
\hline \multicolumn{16}{|l|}{ Transportation and communication costs } \\
\hline Bilateral distances between capital cities (in kilometers) & 504 & 749 & 436 & 1140 & 2296 & 623 & 9534 & 9640 & 7973 & 10399 & 8084 & 11223 & 6441 & 6272 & \\
\hline \multicolumn{16}{|l|}{ Investment costs } \\
\hline Ease of doing business index (1=most business-friendly regulations) & 27 & 6 & 31 & 72 & 118 & 66 & 127 & 55 & 178 & 1 & 86 & 129 & 8 & 4 & 19 \\
\hline Corruption Perceptions Index (1=highest (perceived) corruption) & 7.9 & 7.7 & 6.9 & 4.6 & 2.1 & 5.2 & 3.5 & 3.6 & 1.9 & 9.2 & 3.6 & 2.6 & 8.7 & 7.3 & 9.0 \\
\hline Inflation of consumer prices (annual \%) & 2.6 & 4.0 & 2.8 & 4.3 & 14.1 & 6.4 & 5.7 & 5.1 & 31.4 & 6.5 & 5.9 & 10.1 & 2.4 & 3.8 & 2.4 \\
\hline
\end{tabular}

Notes: To ensure a high degree of comparability with the data of our survey, the year 2008 was chosen as basis for this information. In case of missing data for 2008 , the latest available information was used (but no data is provided if it does not refer to a year later than 2000). Most of the data comes from the Worldbank (Worldbank 2010). Exceptions are the variables ,Share of capital stock of Swiss FDI abroad" (SNB 2010), "Gross hourly pay in a big city" (UBS 2009), "Annual employment income per worker" (World Salaries 2005), "Bilateral distances between capital cities" (CEPII 2010) and "Corruption Perceptions Index" (Transparency International 2008). 
Table 2: Variable definition and measurement

\begin{tabular}{|c|c|}
\hline Variable & Definition / measurement \\
\hline \multicolumn{2}{|l|}{ Dependent variables } \\
\hline $\begin{array}{l}\text { EU15/EFTA; Eastern Europe; North America; } \\
\text { Latin America; Asia }\end{array}$ & $\begin{array}{l}\text { The firm has foreign affiliates in a certain "main" region } \\
\text { (yes/no) }\end{array}$ \\
\hline Eastern Europe; Southeast Europe; Russia & $\begin{array}{l}\text { The firm has foreign affiliates in a certain "sub-region" of } \\
\text { Eastern Europe (yes/no) }\end{array}$ \\
\hline China; Asian Tigers; Southeast Asia/India & $\begin{array}{l}\text { The firm has foreign affiliates in a certain "sub-region" of Asia } \\
\text { (yes/no) }\end{array}$ \\
\hline \multicolumn{2}{|l|}{ Independent variables } \\
\hline first_fdi_1990 & $\begin{array}{l}\text { The firm already had FDI activities before } 1990 \text { (yes/no) } \\
\text { (reference group: firms that started FDI activities after 2000) }\end{array}$ \\
\hline first_fdi_2000 & $\begin{array}{l}\text { The firm started FDI activities between } 1990 \text { and } 2000 \text { (yes/no) } \\
\text { (reference group: firms that started FDI activities after 2000) }\end{array}$ \\
\hline firm_age & Number of years natural logarithm \\
\hline r\&d_intensity & Sales share of R\&D expenditures; natural logarithm \\
\hline tertiary_share & $\begin{array}{l}\text { Share of employees with a tertiary-level degree; natural } \\
\text { logarithm }\end{array}$ \\
\hline employment_growth & $\begin{array}{l}\text { Change of the natural logarithm of the number of employees } \\
\text { between } 2003 \text { and } 2008\end{array}$ \\
\hline inflow & $\begin{array}{l}\text { Share of goods/services that the Swiss parent company } \\
\text { imported from foreign subsidiaries } \\
\text { (nine-level variable: } 0 \%, 1-5 \%, 6-10 \%, 11-15 \%, 16-20 \%, 21-30 \%, 31- \\
40 \%, 41-50 \% \text { and } 51-100 \% \text { ) }\end{array}$ \\
\hline outflow & $\begin{array}{l}\text { Share of goods/services that the Swiss parent company } \\
\text { exported to foreign subsidiaries } \\
\text { (nine-level variable: } 0 \%, 1-5 \%, 6-10 \%, 11-15 \%, 16-20 \%, 21-30 \%, 31- \\
40 \%, 41-50 \% \text { and } 51-100 \% \text { ) }\end{array}$ \\
\hline $\begin{array}{l}\text { sales_motive; institutional_motive; } \\
\text { production_cost_motive; } \\
\text { input_motive }\end{array}$ & $\begin{array}{l}\text { Factor scores of motives for production-oriented FDI (see } \\
\text { Table A.3 in the appendix) }\end{array}$ \\
\hline size & Number of employees 2008; natural logarithm \\
\hline industry & Dummies for the industry affiliation of the firm \\
\hline
\end{tabular}


Table 3: Determinants of the location choice; Model I (Basic model); Multivariate probit estimates

\begin{tabular}{|c|c|c|c|c|c|c|c|c|c|c|c|}
\hline & \multicolumn{5}{|c|}{ All regions } & \multicolumn{3}{|c|}{ Eastern Europe } & \multicolumn{3}{|c|}{ Asia } \\
\hline & EU15/EFTA & $\begin{array}{l}\text { Eastern } \\
\text { Europe }\end{array}$ & $\begin{array}{c}\text { North } \\
\text { America }\end{array}$ & $\begin{array}{c}\text { Latin } \\
\text { America }\end{array}$ & Asia & $\begin{array}{l}\text { Eastern } \\
\text { Europe }\end{array}$ & $\begin{array}{l}\text { Southeast } \\
\text { Europe }\end{array}$ & Russia & China & Asian Tigers & $\begin{array}{l}\text { Asia/ } \\
\text { India } \\
\end{array}$ \\
\hline _cons & $\begin{array}{c}0.219 \\
(0.669)\end{array}$ & $\begin{array}{l}-0.775 \\
(0.497)\end{array}$ & $\begin{array}{c}-2.962 * * * \\
(0.629)\end{array}$ & $\begin{array}{c}-2.695 * * * \\
(0.636)\end{array}$ & $\begin{array}{c}-2.727 * * * \\
(0.588)\end{array}$ & $\begin{array}{c}-0.995 * * \\
(0.493)\end{array}$ & $\begin{array}{c}-1.053 * * \\
(0.529)\end{array}$ & $\begin{array}{c}-2.717 * * * \\
(0.620)\end{array}$ & $\begin{array}{c}-3.145^{* * *} \\
(0.620)\end{array}$ & $\begin{array}{c}-2.600 * * * \\
(0.617)\end{array}$ & $\begin{array}{c}-2.076 * * * \\
(0.596)\end{array}$ \\
\hline first_fdi_1990 & $\begin{array}{c}1.066 * * * \\
(0.226)\end{array}$ & $\begin{array}{c}0.681 * * * \\
(0.184)\end{array}$ & $\begin{array}{c}1.174 * * * \\
(0.231)\end{array}$ & $\begin{array}{c}0.458 * * \\
(0.211)\end{array}$ & $\begin{array}{c}0.914 * * * \\
(0.193)\end{array}$ & $\begin{array}{c}0.649 * * * \\
(0.187)\end{array}$ & $\begin{array}{c}0.664 * * * \\
(0.208)\end{array}$ & $\begin{array}{c}0.961 * * * \\
(0.242)\end{array}$ & $\begin{array}{c}0.860 * * * \\
(0.221)\end{array}$ & $\begin{array}{c}1.049 * * * \\
(0.238)\end{array}$ & $\begin{array}{c}0.781 * * * \\
(0.215)\end{array}$ \\
\hline first_fdi_2000 & $\begin{array}{c}0.569 * * \\
(0.236)\end{array}$ & $\begin{array}{c}0.153 \\
(0.203)\end{array}$ & $\begin{array}{c}0.907 * * * \\
(0.251)\end{array}$ & $\begin{array}{c}0.011 \\
(0.242)\end{array}$ & $\begin{array}{c}0.601 * * * \\
(0.212)\end{array}$ & $\begin{array}{c}0.233 \\
(0.211)\end{array}$ & $\begin{array}{c}0.110 \\
(0.238)\end{array}$ & $\begin{array}{c}0.293 \\
(0.272)\end{array}$ & $\begin{array}{c}0.713 * * * \\
(0.242)\end{array}$ & $\begin{array}{c}0.628 * * \\
(0.259)\end{array}$ & $\begin{array}{c}0.279 \\
(0.241)\end{array}$ \\
\hline firm_age & $\begin{array}{c}-0.024 \\
(0.117)\end{array}$ & $\begin{array}{l}-0.047 \\
(0.087)\end{array}$ & $\begin{array}{l}-0.007 \\
(0.094)\end{array}$ & $\begin{array}{l}-0.109 \\
(0.095)\end{array}$ & $\begin{array}{l}-0.036 \\
(0.089)\end{array}$ & $\begin{array}{c}-0.077 \\
(0.087)\end{array}$ & $\begin{array}{l}-0.120 \\
(0.090)\end{array}$ & $\begin{array}{l}-0.049 \\
(0.095)\end{array}$ & $\begin{array}{c}-0.009 \\
(0.092)\end{array}$ & $\begin{array}{l}-0.042 \\
(0.091)\end{array}$ & $\begin{array}{c}-0.153 * \\
(0.093)\end{array}$ \\
\hline r\&d_intensity & $\begin{array}{c}-0.018 \\
(0.036)\end{array}$ & $\begin{array}{c}0.089 * * * \\
(0.028)\end{array}$ & $\begin{array}{c}0.113 * * * \\
(0.029)\end{array}$ & $\begin{array}{l}0.060 * \\
(0.031)\end{array}$ & $\begin{array}{l}0.047 * \\
(0.027)\end{array}$ & $\begin{array}{c}0.078 * * * \\
(0.028)\end{array}$ & $\begin{array}{c}0.093 * * * \\
(0.030)\end{array}$ & $\begin{array}{c}0.069 * * \\
(0.032)\end{array}$ & $\begin{array}{l}0.048 * \\
(0.029)\end{array}$ & $\begin{array}{l}0.054 * \\
(0.029)\end{array}$ & $\begin{array}{c}0.046 \\
(0.029)\end{array}$ \\
\hline tertiary_share & $\begin{array}{l}-0.007 \\
(0.102)\end{array}$ & $\begin{array}{l}-0.108 \\
(0.072)\end{array}$ & $\begin{array}{c}0.220 * * \\
(0.100)\end{array}$ & $\begin{array}{c}0.332 * * * \\
(0.103)\end{array}$ & $\begin{array}{c}0.349 * * * \\
(0.096)\end{array}$ & $\begin{array}{l}-0.068 \\
(0.071)\end{array}$ & $\begin{array}{l}-0.059 \\
(0.079)\end{array}$ & $\begin{array}{c}0.121 \\
(0.100)\end{array}$ & $\begin{array}{c}0.259 * * \\
(0.102)\end{array}$ & $\begin{array}{c}0.225 * * \\
(0.100)\end{array}$ & $\begin{array}{l}0.164 * \\
(0.096)\end{array}$ \\
\hline employment_growth & $\begin{array}{c}0.443 * * \\
(0.213)\end{array}$ & $\begin{array}{l}-0.202 \\
(0.172)\end{array}$ & $\begin{array}{c}0.160 \\
(0.181)\end{array}$ & $\begin{array}{c}0.176 \\
(0.182)\end{array}$ & $\begin{array}{c}-0.214 \\
(0.177)\end{array}$ & $\begin{array}{c}-0.128 \\
(0.178)\end{array}$ & $\begin{array}{l}-0.236 \\
(0.184)\end{array}$ & $\begin{array}{l}-0.085 \\
(0.192)\end{array}$ & $\begin{array}{c}-0.014 \\
(0.177)\end{array}$ & $\begin{array}{c}-0.184 \\
(0.171)\end{array}$ & $\begin{array}{c}-0.018 \\
(0.170)\end{array}$ \\
\hline size & $\begin{array}{l}0.130 * \\
(0.069)\end{array}$ & $\begin{array}{c}0.172 * * * \\
(0.045)\end{array}$ & $\begin{array}{c}0.217 * * * \\
(0.048)\end{array}$ & $\begin{array}{c}0.203 * * * \\
(0.050)\end{array}$ & $\begin{array}{c}0.193 * * * \\
(0.046)\end{array}$ & $\begin{array}{c}0.179 * * * \\
(0.046)\end{array}$ & $\begin{array}{c}0.150 * * * \\
(0.048)\end{array}$ & $\begin{array}{c}0.234 * * * \\
(0.050)\end{array}$ & $\begin{array}{c}0.208 * * * \\
(0.047)\end{array}$ & $\begin{array}{c}0.137 * * * \\
(0.047)\end{array}$ & $\begin{array}{c}0.216 * * * \\
(0.047)\end{array}$ \\
\hline industry & yes & yes & yes & yes & yes & yes & yes & yes & yes & yes & yes \\
\hline $\begin{array}{l}\mathrm{N} \\
\text { Wald } \mathrm{chi}^{2} \\
\text { LR test of the multivariate probit } \\
\text { against independent univariate probits }\end{array}$ & & & $\begin{array}{c}473 \\
256.16^{* * * *} \\
281.58 * * *\end{array}$ & & & & $\begin{array}{c}473 \\
103.05 * * * \\
255.14 * * *\end{array}$ & & & $\begin{array}{c}473 \\
137.86^{* * * *} \\
270.59^{* * *}\end{array}$ & \\
\hline
\end{tabular}

Notes: See Table 2 for the variable definitions; standard errors are in brackets under the coefficients; ***,**,* denote statistical significance at the $1 \%, 5 \%$ and $10 \%$ test level, respectively. Estimates are based on 100 draws (change in estimates as the number of draws is further increased is negligible). 
Table 4: Descriptive analysis of $R \& D$ activities

\begin{tabular}{|c|c|c|c|c|c|c|c|c|c|c|c|}
\hline & \multicolumn{5}{|c|}{ All regions } & \multicolumn{3}{|c|}{ Eastern Europe } & \multicolumn{3}{|c|}{ Asia } \\
\hline & $\begin{array}{l}\text { EU15/ } \\
\text { EFTA }\end{array}$ & $\begin{array}{l}\text { Eastern } \\
\text { Europe }\end{array}$ & $\begin{array}{c}\text { North } \\
\text { America }\end{array}$ & $\begin{array}{c}\text { Latin } \\
\text { America }\end{array}$ & Asia & $\begin{array}{l}\text { Eastern } \\
\text { Europe } \\
\end{array}$ & $\begin{array}{c}\text { Southeast } \\
\text { Europe }\end{array}$ & Russia & China & $\begin{array}{l}\text { Asian } \\
\text { Tigers }\end{array}$ & $\begin{array}{l}\text { Southeast } \\
\text { Asia/India }\end{array}$ \\
\hline $\begin{array}{l}\text { Percentage share of firms with R\&D activities in Switzerland by FDI } \\
\text { location }\end{array}$ & 70 & 80 & 87 & 83 & 80 & 80 & 81 & 86 & 82 & 81 & 81 \\
\hline $\begin{array}{l}\text { Percentage share of firms with } R \& D \text { activities in a certain region by } \\
\text { FDI location }\end{array}$ & 29 & 9 & 22 & 4 & 14 & 8 & 3 & 3 & 12 & 8 & 7 \\
\hline Correlation of R\&D propensity at home and abroad & 0.36 & 0.16 & 0.17 & -0.02 & 0.14 & 0.15 & 0.08 & 0.07 & 0.08 & 0.08 & 0.13 \\
\hline Number of observations & 422 & 238 & 204 & 119 & 244 & 212 & 135 & 126 & 181 & 158 & 158 \\
\hline
\end{tabular}

Source: Survey on the "Internationalization of the Swiss Economy" (see Section 4). 
Table 5: Determinants of the location choice; Model II (Intra-firm trade flows); Multivariate probit estimates

\begin{tabular}{|c|c|c|c|c|c|c|c|c|c|c|c|}
\hline & \multicolumn{5}{|c|}{ All regions } & \multicolumn{3}{|c|}{ Eastern Europe } & \multicolumn{3}{|c|}{ Asia } \\
\hline & EU15/EFTA & $\begin{array}{l}\text { Eastern } \\
\text { Europe }\end{array}$ & $\begin{array}{c}\text { North } \\
\text { America }\end{array}$ & $\begin{array}{c}\text { Latin } \\
\text { America }\end{array}$ & Asia & $\begin{array}{l}\text { Eastern } \\
\text { Europe }\end{array}$ & $\begin{array}{l}\text { Southeast } \\
\text { Europe }\end{array}$ & Russia & China & Asian Tigers & $\begin{array}{l}\text { Asia/ } \\
\text { India }\end{array}$ \\
\hline _cons & $\begin{array}{l}-0.946 \\
(1.024)\end{array}$ & $\begin{array}{l}-0.642 \\
(0.744)\end{array}$ & $\begin{array}{c}-3.001 * * * \\
(0.778)\end{array}$ & $\begin{array}{c}-2.969 * * * \\
(0.820)\end{array}$ & $\begin{array}{c}-2.962 * * * \\
(0.763)\end{array}$ & $\begin{array}{c}-1.396^{*} \\
(0.718)\end{array}$ & $\begin{array}{l}-0.201 \\
(0.738)\end{array}$ & $\begin{array}{c}-3.010^{* * *} \\
(0.819)\end{array}$ & $\begin{array}{c}-4.137 * * * \\
(0.825)\end{array}$ & $\begin{array}{c}-2.616^{* * *} \\
(0.795)\end{array}$ & $\begin{array}{c}-2.069 * * * \\
(0.764)\end{array}$ \\
\hline first_fdi_1990 & $\begin{array}{c}1.006 * * * \\
(0.284)\end{array}$ & $\begin{array}{c}0.568 * * \\
(0.225)\end{array}$ & $\begin{array}{c}1.138 * * * \\
(0.272)\end{array}$ & $\begin{array}{c}0.517 * * \\
(0.258)\end{array}$ & $\begin{array}{c}1.153 * * * \\
(0.240)\end{array}$ & $\begin{array}{c}0.572 * * \\
(0.228)\end{array}$ & $\begin{array}{c}0.486 * * \\
(0.247)\end{array}$ & $\begin{array}{c}0.827 * * * \\
(0.294)\end{array}$ & $\begin{array}{c}1.184 * * * \\
(0.281)\end{array}$ & $\begin{array}{c}1.110 * * * \\
(0.294)\end{array}$ & $\begin{array}{c}0.962 * * * \\
(0.272)\end{array}$ \\
\hline first_fdi_2000 & $\begin{array}{l}0.491 * \\
(0.291)\end{array}$ & $\begin{array}{c}0.009 \\
(0.248)\end{array}$ & $\begin{array}{c}0.959 * * * \\
(0.293)\end{array}$ & $\begin{array}{c}-0.059 \\
(0.290)\end{array}$ & $\begin{array}{c}0.747 * * * \\
(0.260)\end{array}$ & $\begin{array}{c}0.204 \\
(0.253)\end{array}$ & $\begin{array}{c}-0.027 \\
(0.279)\end{array}$ & $\begin{array}{c}0.239 \\
(0.328)\end{array}$ & $\begin{array}{c}0.980 * * * \\
(0.303)\end{array}$ & $\begin{array}{c}0.649 * * \\
(0.318)\end{array}$ & $\begin{array}{l}0.493 * \\
(0.297)\end{array}$ \\
\hline firm_age & $\begin{array}{l}-0.025 \\
(0.152)\end{array}$ & $\begin{array}{l}-0.086 \\
(0.116)\end{array}$ & $\begin{array}{l}-0.104 \\
(0.117)\end{array}$ & $\begin{array}{l}-0.064 \\
(0.122)\end{array}$ & $\begin{array}{l}-0.064 \\
(0.113)\end{array}$ & $\begin{array}{l}-0.070 \\
(0.110)\end{array}$ & $\begin{array}{l}-0.166 \\
(0.114)\end{array}$ & $\begin{array}{l}-0.038 \\
(0.120)\end{array}$ & $\begin{array}{c}0.034 \\
(0.118)\end{array}$ & $\begin{array}{c}-0.082 \\
(0.118)\end{array}$ & $\begin{array}{l}-0.200 * \\
(0.117)\end{array}$ \\
\hline r\&d_intensity & $\begin{array}{c}-0.031 \\
(0.046)\end{array}$ & $\begin{array}{c}0.035 \\
(0.036)\end{array}$ & $\begin{array}{c}0.099 * * * \\
(0.037)\end{array}$ & $\begin{array}{c}0.058 \\
(0.039)\end{array}$ & $\begin{array}{l}-0.003 \\
(0.035)\end{array}$ & $\begin{array}{c}0.028 \\
(0.036)\end{array}$ & $\begin{array}{c}0.075^{* *} \\
(0.038)\end{array}$ & $\begin{array}{c}0.021 \\
(0.040)\end{array}$ & $\begin{array}{l}-0.008 \\
(0.037)\end{array}$ & $\begin{array}{c}0.007 \\
(0.037)\end{array}$ & $\begin{array}{c}0.032 \\
(0.036)\end{array}$ \\
\hline tertiary_share & $\begin{array}{l}-0.030 \\
(0.173)\end{array}$ & $\begin{array}{c}-0.252^{* *} \\
(0.123)\end{array}$ & $\begin{array}{c}0.114 \\
(0.126)\end{array}$ & $\begin{array}{c}0.336 * * \\
(0.133)\end{array}$ & $\begin{array}{c}0.335 * * * \\
(0.123)\end{array}$ & $\begin{array}{l}-0.129 \\
(0.118)\end{array}$ & $\begin{array}{l}-0.207 * \\
(0.123)\end{array}$ & $\begin{array}{c}0.060 \\
(0.132)\end{array}$ & $\begin{array}{c}0.335^{* * *} \\
(0.128)\end{array}$ & $\begin{array}{c}0.086 \\
(0.127)\end{array}$ & $\begin{array}{c}0.145 \\
(0.122)\end{array}$ \\
\hline employment_growth & $\begin{array}{c}0.839 * * * \\
(0.319)\end{array}$ & $\begin{array}{l}-0.059 \\
(0.223)\end{array}$ & $\begin{array}{c}0.332 \\
(0.245)\end{array}$ & $\begin{array}{l}0.468^{*} \\
(0.251)\end{array}$ & $\begin{array}{c}0.006 \\
(0.230)\end{array}$ & $\begin{array}{l}-0.004 \\
(0.232)\end{array}$ & $\begin{array}{l}-0.148 \\
(0.236)\end{array}$ & $\begin{array}{c}0.025 \\
(0.246)\end{array}$ & $\begin{array}{c}0.145 \\
(0.234)\end{array}$ & $\begin{array}{c}0.090 \\
(0.230)\end{array}$ & $\begin{array}{c}0.008 \\
(0.226)\end{array}$ \\
\hline size & $\begin{array}{c}0.265^{* * *} * \\
(0.096)\end{array}$ & $\begin{array}{c}0.147^{* *} * \\
(0.060)\end{array}$ & $\begin{array}{c}0.253 * * * \\
(0.063)\end{array}$ & $\begin{array}{c}0.158 * * \\
(0.065)\end{array}$ & $\begin{array}{c}0.177 * * * \\
(0.061)\end{array}$ & $\begin{array}{c}0.166^{* * * *} \\
(0.060)\end{array}$ & $\begin{array}{c}0.058 \\
(0.062)\end{array}$ & $\begin{array}{c}0.218 * * * \\
(0.064)\end{array}$ & $\begin{array}{c}0.184 * * * \\
(0.062)\end{array}$ & $\begin{array}{c}0.137 * * \\
(0.063)\end{array}$ & $\begin{array}{c}0.188 * * * \\
(0.061)\end{array}$ \\
\hline inflow & -0.061 & $0.125^{* * *}$ & 0.015 & $0.060 *$ & $0.084 * *$ & $0.101 * * *$ & $0.056^{*}$ & $0.080^{* *}$ & $0.080 * *$ & 0.034 & $0.079 * *$ \\
\hline outflow & $\begin{array}{c}(0.051) \\
0.185 * * * \\
(0.057)\end{array}$ & $\begin{array}{c}(0.036) \\
0.087 * * * \\
(0.029)\end{array}$ & $\begin{array}{l}(0.036) \\
0.076 * * \\
(0.030)\end{array}$ & $\begin{array}{c}(0.036) \\
0.011 \\
(0.030)\end{array}$ & $\begin{array}{c}(0.036) \\
0.003 \\
(0.029)\end{array}$ & $\begin{array}{c}(0.034) \\
0.085 * * * \\
(0.028)\end{array}$ & $\begin{array}{c}(0.034) \\
0.072 * * * \\
(0.028)\end{array}$ & $\begin{array}{l}(0.036) \\
0.072 * * \\
(0.029)\end{array}$ & $\begin{array}{c}(0.037) \\
0.044 \\
(0.029)\end{array}$ & $\begin{array}{l}(0.035) \\
0.073 * * \\
(0.029)\end{array}$ & $\begin{array}{c}(0.034) \\
0.002 \\
(0.029)\end{array}$ \\
\hline industry & yes & yes & yes & yes & yes & yes & yes & yes & yes & yes & yes \\
\hline $\begin{array}{l}\mathrm{N} \\
\text { Wald chi } \\
\text { LR test of the multivariate probit } \\
\text { against independent univariate probits }\end{array}$ & & & $\begin{array}{c}334 \\
235.03^{* * * *} \\
198.08^{* * * *}\end{array}$ & & & & $\begin{array}{c}334 \\
102.24 * * * \\
156.10 * * *\end{array}$ & & & $\begin{array}{c}334 \\
124.48^{* * *} \\
179.24 * * *\end{array}$ & \\
\hline
\end{tabular}

Notes: See Table 2 for the variable definitions; standard errors are in brackets under the coefficients; ***, **, * denote statistical significance at the $1 \%, 5 \%$ and $10 \%$ test level, respectively. Estimates are based on 100 draws (change in estimates as the number of draws is further increased is negligible). 
Table 6: Determinants of the location choice; Model III (Motives for production-oriented FDI); Multivariate probit estimates

\begin{tabular}{|c|c|c|c|c|c|c|c|c|c|c|c|}
\hline & \multicolumn{5}{|c|}{ All regions } & \multicolumn{3}{|c|}{ Eastern Europe } & \multicolumn{3}{|c|}{ Asia } \\
\hline & EU15/EFTA & $\begin{array}{l}\text { Eastern } \\
\text { Europe }\end{array}$ & $\begin{array}{l}\text { North } \\
\text { America }\end{array}$ & $\begin{array}{l}\text { Latin } \\
\text { America }\end{array}$ & Asia & $\begin{array}{l}\text { Eastern } \\
\text { Europe }\end{array}$ & $\begin{array}{l}\text { Southeast } \\
\text { Europe }\end{array}$ & Russia & China & Asian Tigers & $\begin{array}{l}\text { Asia/ } \\
\text { India }\end{array}$ \\
\hline \multirow[t]{2}{*}{ _cons } & -0.692 & 0.178 & $-2.651 * * *$ & $-3.202 * * *$ & $-1.137 *$ & -0.581 & -0.249 & -0.876 & $-1.474 * *$ & $-1.365^{*}$ & $-1.891 * * *$ \\
\hline & $(0.704)$ & $(0.617)$ & $(0.806)$ & $(0.854)$ & $(0.628)$ & $(0.606)$ & (0.697) & $(0.930)$ & $(0.681)$ & $(0.770)$ & $(0.698)$ \\
\hline \multirow[t]{2}{*}{ first_fdi_1990 } & $0.894 * * *$ & -0.034 & $1.220 * * *$ & -0.019 & $0.582 * * *$ & -0.018 & -0.082 & 0.305 & $0.428^{*}$ & $0.867 * *$ & 0.364 \\
\hline & $(0.231)$ & $(0.215)$ & $(0.327)$ & $(0.272)$ & $(0.225)$ & $(0.221)$ & $(0.266)$ & $(0.404)$ & $(0.259)$ & $(0.343)$ & $(0.263)$ \\
\hline \multirow[t]{2}{*}{ first_fdi_2000 } & $0.661 * *$ & -0.337 & $0.708 * *$ & -0.313 & $0.500^{*}$ & -0.155 & -0.431 & -0.121 & 0.319 & $0.734 * *$ & 0.217 \\
\hline & $(0.265)$ & $(0.254)$ & $(0.357)$ & $(0.326)$ & $(0.256)$ & $(0.259)$ & $(0.317)$ & $(0.462)$ & $(0.290)$ & $(0.370)$ & $(0.300)$ \\
\hline \multirow[t]{2}{*}{ firm_age } & -0.143 & -0.051 & $-0.264 * *$ & 0.018 & -0.135 & -0.019 & -0.157 & $-0.348 * *$ & -0.137 & $-0.237 * *$ & -0.168 \\
\hline & $(0.125)$ & $(0.105)$ & $(0.115)$ & $(0.125)$ & $(0.102)$ & $(0.105)$ & $(0.120)$ & $(0.148)$ & $(0.110)$ & $(0.118)$ & $(0.114)$ \\
\hline \multirow[t]{2}{*}{ r\&d_intensity } & -0.045 & $0.085^{* *}$ & $0.085 * *$ & 0.010 & 0.045 & $0.061 *$ & $0.081^{*}$ & $0.094 *$ & 0.052 & 0.042 & -0.002 \\
\hline & $(0.037)$ & $(0.035)$ & $(0.039)$ & $(0.044)$ & $(0.033)$ & $(0.035)$ & $(0.042)$ & $(0.056)$ & $(0.036)$ & $(0.039)$ & $(0.037)$ \\
\hline \multirow[t]{2}{*}{ tertiary_share } & 0.051 & $-0.208 * *$ & 0.093 & $0.274 * *$ & 0.107 & $-0.179 * *$ & $-0.183 * *$ & -0.057 & 0.053 & -0.002 & 0.087 \\
\hline & $(0.093)$ & $(0.084)$ & $(0.122)$ & $(0.137)$ & $(0.095)$ & $(0.081)$ & $(0.090)$ & $(0.143)$ & $(0.099)$ & $(0.108)$ & $(0.106)$ \\
\hline \multirow[t]{2}{*}{ employment_growth } & 0.129 & -0.121 & -0.020 & -0.095 & 0.124 & -0.209 & -0.261 & -0.190 & 0.209 & -0.056 & 0.028 \\
\hline & $(0.209)$ & $(0.189)$ & $(0.215)$ & $(0.217)$ & $(0.182)$ & $(0.202)$ & $(0.243)$ & $(0.325)$ & $(0.190)$ & $(0.204)$ & $(0.197)$ \\
\hline \multirow[t]{2}{*}{ size } & $0.234 * * *$ & $0.088^{*}$ & $0.285^{* * *}$ & $0.189 * * *$ & $0.094^{*}$ & $0.123 * *$ & 0.091 & $0.173 * *$ & $0.113 * *$ & 0.081 & $0.209 * * *$ \\
\hline & $(0.070)$ & $(0.052)$ & $(0.058)$ & $(0.064)$ & $(0.051)$ & $(0.054)$ & $(0.062)$ & $(0.073)$ & $(0.056)$ & $(0.059)$ & $(0.057)$ \\
\hline \multirow[t]{2}{*}{ sales_motive } & -0.008 & $0.192 * * *$ & $0.239 * * *$ & 0.136 & $0.260 * * *$ & $0.138^{*}$ & $0.316 * * *$ & $0.282 * *$ & $0.325 * * *$ & $0.226 * * *$ & 0.112 \\
\hline & $(0.081)$ & $(0.072)$ & $(0.084)$ & $(0.095)$ & $(0.072)$ & $(0.072)$ & $(0.090)$ & $(0.123)$ & $(0.078)$ & $(0.087)$ & $(0.080)$ \\
\hline \multirow[t]{2}{*}{ institutional_motive } & 0.049 & -0.054 & $0.133^{*}$ & -0.009 & -0.018 & -0.076 & 0.016 & 0.146 & 0.000 & -0.004 & 0.029 \\
\hline & $(0.083)$ & $(0.073)$ & $(0.079)$ & $(0.093)$ & $(0.071)$ & $(0.075)$ & $(0.088)$ & $(0.113)$ & $(0.074)$ & $(0.086)$ & $(0.080)$ \\
\hline \multirow[t]{2}{*}{ production_cost_motive } & $-0.142 *$ & $0.358 * * *$ & -0.056 & 0.163 & $0.169 * *$ & $0.303 * * *$ & $0.211 * *$ & 0.124 & $0.263 * * *$ & -0.043 & $0.145^{*}$ \\
\hline & $(0.086)$ & $(0.079)$ & $(0.086)$ & $(0.101)$ & $(0.075)$ & $(0.079)$ & $(0.095)$ & $(0.122)$ & $(0.081)$ & $(0.088)$ & $(0.082)$ \\
\hline \multirow[t]{2}{*}{ input_motive } & -0.038 & -0.008 & 0.094 & 0.010 & -0.050 & 0.040 & 0.036 & -0.035 & 0.066 & -0.026 & -0.009 \\
\hline & $(0.079)$ & $(0.072)$ & $(0.078)$ & $(0.086)$ & $(0.069)$ & $(0.074)$ & $(0.086)$ & $(0.114)$ & $(0.075)$ & $(0.081)$ & $(0.078)$ \\
\hline industry & yes & yes & yes & yes & yes & yes & yes & yes & yes & yes & yes \\
\hline $\mathrm{N}$ & & & 371 & & & & 371 & & & 371 & \\
\hline Wald chi ${ }^{2}$ & & & $210.01 * * *$ & & & & $86.43 * * *$ & & & $104.25^{* * *}$ & \\
\hline $\begin{array}{l}\text { LR test of the multivariate probit against } \\
\text { independent univariate probits }\end{array}$ & & & $117.50 * * *$ & & & & $74.85 * * *$ & & & $92.32 * * *$ & \\
\hline
\end{tabular}

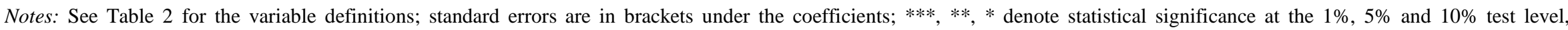
respectively. Estimates are based on 100 draws (change in estimates as the number of draws is further increased is negligible). 
Appendix 
Table A.1: Descriptive statistics

\begin{tabular}{|c|c|c|c|c|c|c|c|}
\hline \multicolumn{2}{|l|}{ Variables } & \multicolumn{2}{|c|}{$\begin{array}{l}\text { Model I } \\
\mathrm{N}=473\end{array}$} & \multicolumn{2}{|c|}{$\begin{array}{l}\text { Model II } \\
\mathrm{N}=334\end{array}$} & \multicolumn{2}{|c|}{$\begin{array}{l}\text { Model III } \\
\text { N=371 }\end{array}$} \\
\hline Dependent variables & & & & & & & \\
\hline EU15/EFTA & binary & 0.892 & 0.310 & 0.880 & 0.325 & 0.822 & 0.383 \\
\hline Eastern Europe & binary & 0.503 & 0.501 & 0.542 & 0.499 & 0.356 & 0.479 \\
\hline North America & binary & 0.431 & 0.496 & 0.455 & 0.499 & 0.256 & 0.437 \\
\hline Latin America & binary & 0.252 & 0.434 & 0.272 & 0.446 & 0.116 & 0.321 \\
\hline Asia & binary & 0.516 & 0.500 & 0.548 & 0.498 & 0.407 & 0.492 \\
\hline Independent variables & & & & & & & \\
\hline first_fdi_1990 & binary & 0.611 & 0.488 & 0.608 & 0.489 & 0.623 & 0.485 \\
\hline first_fdi_2000 & binary & 0.247 & 0.432 & 0.240 & 0.427 & 0.235 & 0.424 \\
\hline firm_age & continuous & 3.974 & 0.766 & 4.031 & 0.740 & 3.974 & 0.767 \\
\hline r\&d_intensity & continuous & -1.096 & 2.636 & -0.881 & 2.585 & -1.084 & 2.617 \\
\hline tertiary_share & continuous & 3.039 & 0.965 & 3.125 & 0.739 & 3.051 & 1.012 \\
\hline employment_growth & continuous & 0.087 & 0.368 & 0.099 & 0.338 & 0.083 & 0.391 \\
\hline size & continuous & 5.040 & 1.487 & 5.234 & 1.379 & 5.170 & 1.547 \\
\hline inflow & ordinal & & & 2.862 & 2.292 & & \\
\hline outflow & ordinal & & & 4.437 & 2.913 & & \\
\hline sales_motive & continuous & & & & & -0.040 & 1.018 \\
\hline institutional_motive & continuous & & & & & 0.014 & 1.029 \\
\hline production_cost_motive & continuous & & & & & -0.001 & 1.003 \\
\hline input_motive & continuous & & & & & 0.048 & 0.988 \\
\hline
\end{tabular}

Notes: The factor analysis that is used to identify the four groups of motives (sales_motive, institutional_motive, production_cost motive and input motive) contains all observations available. Due to missing values for other model variables, the number of observations that could be used in the regression of Model III is smaller (371 observations compared to 473 in the factor analysis). Therefore, the mean of the factor scores in the regression differs from zero. 
Table A.2: Correlation matrix (based on Model I; $\mathbf{N}=473$ )

\begin{tabular}{|c|c|c|c|c|c|c|c|c|c|c|c|}
\hline & EU15/EFTA & Eastern Europe & $\begin{array}{c}\text { North } \\
\text { America }\end{array}$ & $\begin{array}{c}\text { Latin } \\
\text { America }\end{array}$ & Asia & $\begin{array}{c}\text { first_fdi_ } \\
1990\end{array}$ & $\begin{array}{l}\text { first_fdi_ } \\
2000\end{array}$ & firm_age & $\mathrm{r}_{\text {intensity }}$ & $\begin{array}{c}\text { tertiary_ } \\
\text { share }\end{array}$ & $\begin{array}{c}\text { employment_ } \\
\text { growth }\end{array}$ \\
\hline Eastern Europe & 0.036 & & & & & & & & & & \\
\hline North America & 0.110 & 0.379 & & & & & & & & & \\
\hline Latin America & 0.123 & 0.440 & 0.440 & & & & & & & & \\
\hline Asia & 0.004 & 0.433 & 0.485 & 0.493 & & & & & & & \\
\hline first_fdi_1990 & 0.198 & 0.239 & 0.266 & 0.193 & 0.225 & & & & & & \\
\hline first_fdi_2000 & -0.069 & -0.165 & -0.094 & -0.129 & -0.072 & -0.719 & & & & & \\
\hline firm_age & 0.038 & 0.082 & 0.088 & 0.003 & 0.025 & 0.221 & -0.202 & & & & \\
\hline r\&d_intensity & 0.020 & 0.228 & 0.354 & 0.208 & 0.252 & 0.184 & -0.098 & 0.064 & & & \\
\hline tertiary_share & -0.004 & -0.024 & 0.137 & 0.159 & 0.193 & 0.052 & -0.012 & -0.110 & 0.239 & & \\
\hline employment_growth & 0.109 & -0.019 & 0.048 & 0.074 & -0.029 & -0.031 & 0.003 & -0.095 & 0.043 & -0.013 & \\
\hline Size & 0.101 & 0.180 & 0.216 & 0.217 & 0.165 & 0.098 & -0.147 & 0.206 & 0.105 & 0.051 & 0.142 \\
\hline
\end{tabular}


Table A.3: Principal components factor analysis of motives for production-oriented FDI (rotated factor loadings; factor pattern matrix)

\begin{tabular}{|c|c|c|c|c|}
\hline Production & Factor 1 & Factor 2 & Factor 3 & Factor 4 \\
\hline \multicolumn{5}{|l|}{ Motives: } \\
\hline Using investments as a platform for exports to third markets & 0.19 & -0.02 & -0.04 & 0.03 \\
\hline Securing/gaining market shares & 0.24 & -0.07 & 0.01 & -0.07 \\
\hline Expanding existing markets & 0.26 & -0.02 & -0.11 & -0.03 \\
\hline Main customer is located in target region & 0.22 & -0.01 & -0.01 & -0.13 \\
\hline Main competitor is located in target region & 0.18 & -0.02 & 0.03 & -0.04 \\
\hline Seeking early market presence to gain competitive advantages & 0.22 & -0.07 & -0.02 & 0.03 \\
\hline Overcoming trade barriers & 0.11 & -0.03 & 0.01 & 0.13 \\
\hline Larger supply of natural resources & -0.03 & -0.02 & -0.14 & 0.49 \\
\hline Larger supply of intermediate products & -0.07 & -0.12 & -0.03 & 0.55 \\
\hline Reducing transportation costs & 0.06 & -0.11 & 0.11 & 0.21 \\
\hline Larger supply of qualified personnel & -0.01 & 0.15 & 0.03 & -0.04 \\
\hline Larger supply of low qualified personnel & 0.00 & -0.06 & 0.30 & -0.06 \\
\hline Lower labor costs & -0.04 & -0.10 & 0.43 & -0.14 \\
\hline Better access to infrastructure services & -0.02 & 0.01 & 0.26 & -0.09 \\
\hline Supplying the parent company at low costs & -0.07 & -0.19 & 0.36 & 0.15 \\
\hline Avoiding CHF currency risk & -0.03 & 0.12 & 0.04 & 0.06 \\
\hline Tax advantages / investment grants & -0.05 & 0.28 & -0.03 & -0.11 \\
\hline More flexible labor market regulations & -0.06 & 0.31 & -0.03 & -0.13 \\
\hline Less strict environmental laws & -0.04 & 0.30 & -0.17 & 0.04 \\
\hline Less restrictive licensing system & -0.06 & 0.39 & -0.20 & -0.05 \\
\hline \multicolumn{5}{|l|}{ Statistics: } \\
\hline Number of observations & 428 & & & \\
\hline Kaiser-Meyer-Olkin measure of sampling adequacy & 0.909 & & & \\
\hline Variance explained by each factor & 3.867 & 3.619 & 2.823 & 1.928 \\
\hline Final communality estimate & 12.237 & & & \\
\hline \multicolumn{5}{|c|}{ Characterization of the two factors based on the factor pattern: } \\
\hline \multicolumn{5}{|l|}{ Factor 1: sales_motive } \\
\hline \multicolumn{5}{|l|}{ Factor 2: institutional_motive } \\
\hline \multicolumn{5}{|l|}{ Factor 3: production_cost_motive } \\
\hline Factor 4: input_motive & & & & \\
\hline
\end{tabular}

